\title{
Critical Attributes in Service Quality \& Passengers Satisfaction: An Empirical Study of UPSRTC in Agra District
}

\author{
Manoj Kumar * \\ Asst. Professor, \\ Indus Business Academy, Greater Noida \\ (mkumar@ibagreaternoida.org) \\ Madhu Anand, $\mathrm{PhD}$ ** \\ Dr. DS Kothari Post Doc Fellow, \\ Dr. BR Ambedkar University, Agra \\ (madhuanand1@gmail.com)
}

\begin{abstract}
The primary purpose of this study is to explore the quality and performance of public transportation services provided by Uttar Pradesh State Road Transport Corporation (UPSRTC) in giving satisfaction to the customers. Customer satisfaction is a central concept in modern business thoughts and practices. This concept emphasizes delivering satisfaction to consumers, obtaining profits and customer loyalty in return. If there are no buyers to what a firm is producing as goods and/or as services, it makes no meaning of continuing the business. Amid cut-throat competition of today, however, selling of goods and services is no more an easy job. UPSRTC is also facing competition from private transport service providers and neighboring state transportation corporations. This paper explores the generic service quality issues and attributes concerning customer satisfaction. It also illustrate that the demands for the improvements are high as the customer are very dissatisfied about the quality of services, in all the attributes chosen except one, being offered by UPSRTC. The only attribute showing high satisfaction among passengers is that the travel using UPSRTC is cheaper.
\end{abstract}

Keywords: Passengers, Satisfaction, UPSRTC, Quality, Services

\section{1) INTRODUCTION}

UPSRTC is a public sector passenger road transport corporation providing services in the state of Uttar
Pradesh and other adjoining states in North India. With a fleet size of around 7668 buses it operates over 2.5 million kilometers catering to the travel needs of over 1.3 million people and earning over Rs. 38.3 million per day as on date.

Passenger road transport services in the state of U.P. started on 15th May, 1947 with the operation of bus service on the Lucknow - Barabanki route by the erstwhile U.P. Government Roadways. Subsequently, during the fourth Five Year Plan, the erstwhile UP Government Roadways was rechristened as Uttar Pradesh State Road Transport Corporation (UPSRTC) on 01-06-1972 under the provisions of the Road Transport Act, 1950 with the following objectives:

- For the development of the road transport sector correlated to which would be the overall development of trade \& industry.

- For coordination of the road transport services with other modes of transport.

- For providing or causing the provision of an adequate, economical and efficiently coordinated road transport service to the residents of the state

At the time of establishment of the Corporation it had a fleet of 4253 buses which were operating on 1123 routes. The corporation's earned kilometers operated at that time were 228.8 million kilometers. While the total number of passengers carried by its buses totaled 251.3 million. By the end of the decade the fleet of the corporation had attained strength of 5679 buses, the operations had increased to 1782 routes. As a result of this increase in operations, the earned kilometers 
totaled about 395.3 million kilometers, while the total numbers of passengers carried totaled over 449.1 million.

The end of the VI five-year plan saw a further increase in all operational parameters being achieved by the corporation. With the increase in fleet strength of 6198 buses, the earned kilometers of the corporation rose to 425.7 million kilometers. During the VII five year plan emphasis was placed on strengthening the fleet of the corporation. By the end of the plan period the fleet had risen to 8161 buses from the initial strength of 6198. By 1989-90, the Corporation operated 2525 routes covering 648.6 million kilometers and carrying 471.2 million passengers. During the VIII five year plan 2722 buses were replaced with new buses however 3142 buses were auctioned and the fleet at the end of 1996-97 became 7463 buses. During the IX five year plan 2427 buses were replaced and 3785 buses were auctioned, At the end of 2001-02 the Corporation had 6105 buses. In the Xth five year plan 5274 buses were inducted and 4818 buses were removed from fleet. At the end of 2006-07 the Corporation had 6561 buses apart from 784 hired buses operated under its control. During the XI th five year plan period the Corporation targets to purchase 11100 new buses out of which 1725 buses shall be AC, to bring its fleet size to 11261 by the end of the plan period in 2012. The Corporation has also commenced the operation of AC Buses (HIMANI, SHEETAL \& SHATABDI) and non stop inter city services (PAWAN \& PAWAN GOLD). It operates low cost Janta services on shuttle routes and urban \& suburban services in 6 select cities.

\section{2) INFRASTRUCTURE}

The corporate office of the UPSRTC is situated at Lucknow. For efficient functioning the corporation has been divided into 19 regions of which 2 regions operate urban \& sub-urban services. Each region has a regional workshop where major repair and maintenance work as well as assembly reconditioning work is performed. Each region has been further divided into operational units called depots. The total number of depots in the corporation is 108, including car-section. Each depot has a depot workshop attached to it to provide supportive maintenance facilities. For heavy maintenance and repair of vehicles, reconditioning of major assemblies, renovation of buses and construction of bodies on new chassis, two Central workshops have been established in Kanpur: Central Workshop, Rawatpur and Dr. Ram Manohar Lohia Workshop, Allen Forest. Six tyre retreading plants are established at Gorakhpur, Ghaziabad, Bareilly, Kanpur, Saharanpur and Allahabad to provide in-house tyre retreading facilities. For imparting training to drivers and technical staff, a Training School is established in Kanpur. The location details of the various units of UPSRTC are available in the list of regions.

\begin{tabular}{|c|c|c|}
\hline S. No. & Region & No. of Depots \\
\hline 1 & Agra & 8 \\
\hline 2 & Ghaziabad & 7 \\
\hline 3 & Meerut & 4 \\
\hline 4 & Saharanpur & 4 \\
\hline 5 & Aligarh & 7 \\
\hline 6 & Moradabad & 5 \\
\hline 7 & Bareilly & 4 \\
\hline 8 & Hardoi & 5 \\
\hline 9 & Etawah & 6 \\
\hline 10 & Kanpur & 7 \\
\hline 11 & Jhansi & 2 \\
\hline 12 & Lucknow & 6 \\
\hline 13 & Faizabad & 4 \\
\hline 14 & Devipatan & 3 \\
\hline 15 & Chitrakoot & 4 \\
\hline 16 & Allahabad & 8 \\
\hline 17 & Azamgarh & 7 \\
\hline 18 & Gorakhpur & 6 \\
\hline 19 & Varanasi & 7 \\
\hline 20 & Noida & 1 \\
\hline \multirow[t]{2}{*}{21} & Lucknow Mahanagar Parivahan Sewa & 2 \\
\hline & & Total : 107 \\
\hline
\end{tabular}

\section{3) ORGANIZATION}

The Corporation is an autonomous body corporate and its general superintendence, direction and management of affairs and business is vested in a Board of Directors. The management of UPSRTC is 
done by the Board of Directors through its Managing Director who is the Executive Head. The Board is headed by the Chairman and consists of at least 5 or at most 17 Directors, out of whom one-third are from the Central government and two-thirds from the state government. The appointment of the Directors is done by state government.

The management comprises of the Additional Managing Director, Secretary Corporation, Chief General Manager (Operations), Chief General Manager (Technical), Finance Controller, Chief Security Officer, Chief General Manager (Administration) and the General Managers of the functional areas - Operations, Bus Station Management, Passenger Amenities, Personnel, MIS \& EDP, Technical, Materials Management and Quality Control.

The corporation has 65 class I officers, 250 class II officers, 27503 class III (including over 19318 conductors $\&$ drivers) and 7448 class IV staff in a total staff strength of around 35266. Additionally there are 151 daily wages \& part time workers.

\section{4) REVIEW OF LITERATURES}

Andreassen (1995), reported that public services are offered to the public based on the principle of equality. He discussed about customer (dis)satisfaction with public transportation service through his empirical study which was built of 1,000 customers using either bus or train or tram in and around the greater area of the capital of Norway. He concluded that the industry, overall, has a low customer satisfaction.

Jen, Tu \& Lu (2011), in their paper sought to improve understanding of passengers' behavioral intention through a causal relationship model that considers service quality and satisfaction as study parameters.

Yuan-Chih Huang, Chih-Hung Wu, \& Jovan ChiaJung Hsu (2006) in their paper discussed the relationship among customers' characteristics, customers' travelling characteristics and service quality. The paper evaluated the 24 questions' mean value of expected service quality and perceived service quality and suggested that companies separately select a suitable service strategy for different groups of passengers.
Disney, J. (1999) reviewed generic issues concerning customer satisfaction and loyalty in UK and illustrated trends in customer behavior. He also concluded that customer expectations are rising while transport operators becoming more innovative in their attempts to attract and retain customers.

Dawkins, P. and Reichheld, F. (1990); Parasuraman A., Zeithaml, and Berry 1985; Reichheld, F. and W. Earl Sasser, Jr. (1990); Parasuraman, A. and Berry, Leonard L. (1990) in their respective papers concluded that delivering quality service is considered as one of the key and essential strategies for success and survival of business in today's competitive environment.

Referring to the claims made by UPSRTC on its website that its services have undergone a revolution in the last decade and also being the largest public transport provider in Uttar Pradesh State, we conducted this study to determine whether UPSRTC really meets the expectations of the passengers amid availability of increasing choices of transportation from private as well as neighboring state transport corporations.

\section{5) OBJECTIVES OF THE STUDY}

Following are the objectives of this study:

1. To analyze demographic factors of UPSRTC customers

2. To analyze their satisfaction of passengers towards quality of services being offered by UPSRTC

\section{6) METHODOLOGY}

In order to analyze the research objectives and measure the passengers' satisfaction the descriptive research design is considered. In this study we have collected data both from primary and secondary sources. To measure the levels of passengers' satisfaction towards the quality of services provided by UPSRTC, a questionnaire was designed to collect primary data. Various service quality attributes were selected to study the satisfaction and the questionnaire were circulated to few respondents initially to collect data. This pilot study was encouraging and helped us to omit few and include 
some more important attributes which were missing in the original questionnaire. The final draft of the questionnaire was prepared after thorough deliberation and correction. In the final draft of the questionnaire it was decided that the consumer's satisfaction will be measured for service quality attributes such as number of buses, cleanliness, drivers' attitude and behavior, safety, timings etc.

For data collection it was decided to use judgmental sampling and the respondents were selected on the basis of judgments. Any respondents who were below 18 years of age or travelling a few times in the year were not considered for the study. Only passengers, who are regular commuters and using both UPSRTC buses and private or other state transport corporations' services, were only considered for the study.

The primary data is then collected through questionnaire which uses a 5-point scaling technique. A field survey is conducted at various bus stands in Agra district to collect data. The following care was taken in selecting passengers as sample of study:

a. The sample of study consisted randomly selected passengers from all the regions within Agra district

b. The sample of study free from any biasness such as gender, cast, religion etc and represents all the demographic classifications c. If the age of passenger was below 18 years, they were omitted from being part of the sample. This ensures adulthood and maturity of the surveyed passengers

Total sample size is of 400 passengers. There were 250 passengers from each of both rural and urban areas. The selected passengers then were asked to fillin survey. The questions were explained to their best understanding. In case of illiterate passengers, we have assisted them to understand the questions and their response were noted by us onto survey form. The collected data was analyzed to examine the satisfaction of the passengers towards the service quality of UPSRTC in Agra district. The secondary data was collected from the UPSRTC website and their office in Agra etc.

\section{7) SCOPE OF STUDY}

The results of the study generate information, which can be used by UPSRTC towards improving the quality of services being offered to the passengers in the state.

\section{8) DATA ANALYSIS}

The study uses statistical tools such as classification, percentage and scaling techniques to study the levels of satisfaction of services of UPSRTC. The details of the respondents are described in the tables below.

Table 1 below represents the data as inhabitant classification of the respondents

\begin{tabular}{|c|c|c|}
\hline Inhabitation & Passengers Surveyed & Percentage out of Total \\
\hline Rural & 200 & $50 \%$ \\
\hline Urban & 200 & $50 \%$ \\
\hline Total & $\mathbf{4 0 0}$ & $\mathbf{1 0 0} \%$ \\
\hline
\end{tabular}

Source: Primary Data

The data in Table 1 above reveals that equal importance is given to both urban and rural passengers in collecting the data. 
Table 2 below represents the data in gender-wise classification of the respondents:

Table 2: Passengers' Gender-wise Classification

\begin{tabular}{|c|c|c|c|c|c|c|}
\hline & & Male & & Female & & Total \\
\hline & & & $\begin{array}{c}\text { Percentage } \\
\text { out of Total } \\
\text { Males }\end{array}$ & & $\begin{array}{c}\text { Percentage } \\
\text { out of Total } \\
\text { Females }\end{array}$ & \\
\hline & & 100 & $67 \%$ & 50 & $33 \%$ & 150 \\
\hline & $\begin{array}{l}\text { Percentage out } \\
\text { of Total Rural }\end{array}$ & $40 \%$ & & $33 \%$ & & \\
\hline \multirow[b]{2}{*}{ 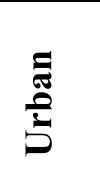 } & & 150 & $60 \%$ & 100 & $40 \%$ & 250 \\
\hline & $\begin{array}{l}\text { Percentage out } \\
\text { of Total Urban }\end{array}$ & $60 \%$ & & $67 \%$ & & \\
\hline Total & & 250 & & 150 & & 400 \\
\hline
\end{tabular}

Source: Primary Data

It can be inferred from the above table 2 that out of total sample of passengers from the Agra district, $62.5 \%$ is male and $37.5 \%$ is female. There were $40 \%$ rural and $60 \%$ urban male passengers out of total sample while $33 \%$ rural and $67 \%$ urban female passengers. Further, we can say that male passengers outnumbered female passengers in both rural and urban samples.

Table 3 below represents the age-wise data of the respondents:

\begin{tabular}{|c|c|c|c|c|c|}
\hline $\begin{array}{c}\text { Age } \\
\text { Group }\end{array}$ & $\begin{array}{c}\text { Rural } \\
\text { (Male) }\end{array}$ & $\begin{array}{c}\text { Rural } \\
\text { (Female) }\end{array}$ & $\begin{array}{c}\text { Urban } \\
\text { (Male) }\end{array}$ & $\begin{array}{c}\text { Urban } \\
\text { (Female) }\end{array}$ & Total \\
\hline $26-35$ & 15 & 12 & 38 & 25 & $\mathbf{1 0 0}$ \\
\hline $36-45$ & 25 & 9 & 34 & 22 & $\mathbf{8 4}$ \\
\hline $46-55$ & 20 & 11 & 30 & 22 & $\mathbf{8 4}$ \\
\hline 56 and & 15 & 5 & 20 & 10 & $\mathbf{8 2}$ \\
\hline above & & $\mathbf{5 0}$ & $\mathbf{1 5 0}$ & $\mathbf{1 0 0}$ & $\mathbf{4 0 0}$ \\
\hline Total & $\mathbf{1 0 0}$ & $\mathbf{5 0}$ & & & \\
\hline
\end{tabular}

Source: Primary Data 
The above Table 3 indicates that our sample consisted of passengers from the age of 18 to senior citizens. The passengers below 18 years were not considered as to restrict the data of adult passengers only. Out of total passengers, $25 \%$ were in the age group of $18-25$ years, $21 \%$ in $26-35$ years, $21 \%$ in $36-45$ years, $20.5 \%$ in $46-55$ years and $12.5 \%$ in 56 and above age groups. The data above also reveals that most passengers, who were frequent travelers, belonged to the age group of 18-25 years. It also indicates that the lowest passengers were in the age group of 56 and above (senior citizens).

Next, Table 4 below represents the education level of the respondents. It can be inferred from the data that approximately $35 \%$ of the passengers in our sample were either illiterate or educates upto high school only. There were $23 \%$ passengers who were educated upto intermediate and approximately $42 \%$ were graduates and post graduates.

Table 4: Passengers' Qualification

\begin{tabular}{|c|c|c|c|c|c|}
\hline Passengers & $\begin{array}{c}\text { Rural } \\
\text { (Male) }\end{array}$ & $\begin{array}{c}\text { Rural } \\
\text { (Female) }\end{array}$ & $\begin{array}{c}\text { Urban } \\
\text { (Male) }\end{array}$ & $\begin{array}{c}\text { Urban } \\
\text { (Female) }\end{array}$ & Total \\
\hline Illiterate & 25 & 37 & 05 & 09 & $\mathbf{7 6}$ \\
\hline Upto High School & 20 & 12 & 12 & 21 & $\mathbf{6 5}$ \\
\hline Upto Intermediate & 35 & 01 & 23 & 33 & $\mathbf{9 2}$ \\
\hline Upto Graduation & 18 & Nil & 58 & 22 & $\mathbf{9 8}$ \\
\hline Post Graduation & 02 & Nil & 52 & 15 & $\mathbf{6 9}$ \\
\hline Total & $\mathbf{1 0 0}$ & $\mathbf{5 0}$ & $\mathbf{1 5 0}$ & $\mathbf{1 0 0}$ & $\mathbf{4 0 0}$ \\
\hline
\end{tabular}

Source: Primary Data

Since we also wanted to study the religion and caste base classification of respondents, the Table 5 below represents the religion-wise and Table 6 represents caste base classification of the respondents:

Table 5: Passengers' Religion

\begin{tabular}{|c|c|c|c|c|c|}
\hline Passengers & $\begin{array}{c}\text { Rural } \\
\text { (Male) }\end{array}$ & $\begin{array}{c}\text { Rural } \\
\text { (Female) }\end{array}$ & $\begin{array}{c}\text { Urban } \\
\text { (Male) }\end{array}$ & $\begin{array}{c}\text { Urban } \\
\text { (Female) }\end{array}$ & Total \\
\hline Hindu & 70 & 35 & 90 & 65 & $\mathbf{2 6 0}$ \\
\hline Muslim & 25 & 05 & 30 & 25 & $\mathbf{8 5}$ \\
\hline Other & 05 & 10 & 30 & 10 & $\mathbf{5 5}$ \\
\hline Total & $\mathbf{1 0 0}$ & $\mathbf{5 0}$ & $\mathbf{1 5 0}$ & $\mathbf{1 0 0}$ & $\mathbf{4 0 0}$ \\
\hline
\end{tabular}

Source: Primary Data

Table 6: Passengers' Caste

\begin{tabular}{|c|c|c|c|c|c|}
\hline Passengers & $\begin{array}{c}\text { Rural } \\
\text { (Male) }\end{array}$ & $\begin{array}{c}\text { Rural } \\
\text { (Female) }\end{array}$ & $\begin{array}{c}\text { Urban } \\
\text { (Male) }\end{array}$ & $\begin{array}{c}\text { Urban } \\
\text { (Female) }\end{array}$ & Total \\
\hline General & 63 & 21 & 91 & 57 & $\mathbf{2 3 2}$ \\
\hline SC / ST & 21 & 17 & 28 & 21 & $\mathbf{8 7}$ \\
\hline OBC & 16 & 12 & 31 & 22 & $\mathbf{8 1}$ \\
\hline Total & $\mathbf{1 0 0}$ & $\mathbf{5 0}$ & $\mathbf{1 5 0}$ & $\mathbf{1 0 0}$ & $\mathbf{4 0 0}$ \\
\hline
\end{tabular}


Table 7: Passengers' Occupations

\begin{tabular}{|c|c|c|c|c|c|}
\hline Occupation & Rural (Male) & $\begin{array}{c}\text { Rural } \\
\text { (Female) }\end{array}$ & $\begin{array}{c}\text { Urban } \\
\text { (Male) }\end{array}$ & $\begin{array}{c}\text { Urban } \\
\text { (Female) }\end{array}$ & Total \\
\hline Govt. Employee & 10 & 02 & 67 & 19 & $\mathbf{9 8}$ \\
\hline Pvt. Employee & 34 & 01 & 39 & 12 & $\mathbf{8 6}$ \\
\hline Agriculture & 33 & 19 & 05 & 01 & $\mathbf{5 8}$ \\
\hline Business & 16 & Nil & 17 & 03 & $\mathbf{3 6}$ \\
\hline $\begin{array}{c}\text { Housewife } \\
\text { or Student }\end{array}$ & 07 & 28 & 22 & 65 & $\mathbf{1 2 2}$ \\
\hline Total & $\mathbf{1 0 0}$ & $\mathbf{5 0}$ & $\mathbf{1 5 0}$ & $\mathbf{1 0 0}$ & $\mathbf{4 0 0}$ \\
\hline
\end{tabular}

Source: Primary Data

It can be inferred that there were $24.5 \%$ Government employees, $21.5 \%$ were privately employed, $14.5 \%$ were farmers, $9 \%$ were businessmen and $30.5 \%$ were either housewives or students among the total sample of passengers surveyed.

Next, in Table 8 below data represents the family system-wise classification of the respondents:

\begin{tabular}{|c|c|c|c|c|c|}
\hline Family Type & Rural (Male) & $\begin{array}{c}\text { Rural } \\
\text { (Female) }\end{array}$ & $\begin{array}{c}\text { Urban } \\
\text { (Male) }\end{array}$ & $\begin{array}{c}\text { Urban } \\
\text { (Female) }\end{array}$ & Total \\
\hline Nucleus & 12 & 05 & 111 & 58 & $\mathbf{1 8 6}$ \\
\hline Joint & 88 & 45 & 39 & 42 & $\mathbf{2 1 4}$ \\
\hline Total & $\mathbf{1 0 0}$ & $\mathbf{5 0}$ & $\mathbf{1 5 0}$ & $\mathbf{1 0 0}$ & $\mathbf{4 0 0}$ \\
\hline
\end{tabular}

Source: Primary Data

The data above clearly indicates that most of the (combined), which were only $38 \%$ in the sample data. passengers belonged to joint family system of the Also, a total of $91 \%$ belonged to nucleus families society. A total of combined male and female amongurban passengers.

respondents with 53.5\% belonged to joint families Below Table 9 describes the classification of the and $46.5 \%$ belonged to nucleolus families. Rural respondents based upon number of dependents on passenger (combined) with $62 \%$ belonging to joint the individual. family system outnumbered urban passengers

Table 9: Number of Dependents-wise Classification

\begin{tabular}{|c|c|c|c|c|c|}
\hline $\begin{array}{c}\text { No. of } \\
\text { Dependents }\end{array}$ & $\begin{array}{c}\text { Rural } \\
\text { (Male) }\end{array}$ & $\begin{array}{c}\text { Rural } \\
\text { (Female) }\end{array}$ & $\begin{array}{c}\text { Urban } \\
\text { (Male) }\end{array}$ & $\begin{array}{c}\text { Urban } \\
\text { (Female) }\end{array}$ & Total \\
\hline 0 to 1 & 26 & 21 & 25 & 24 & $\mathbf{9 6}$ \\
\hline 2 to 3 & 14 & 18 & 39 & 32 & $\mathbf{1 0 3}$ \\
\hline 4 to 5 & 21 & 07 & 43 & 29 & $\mathbf{1 0 0}$ \\
\hline 6 to 8 & 33 & 03 & 27 & 13 & $\mathbf{7 6}$ \\
\hline More than 8 & 06 & 01 & 16 & 02 & $\mathbf{2 5}$ \\
\hline Total & $\mathbf{1 0 0}$ & $\mathbf{5 0}$ & $\mathbf{1 5 0}$ & $\mathbf{1 0 0}$ & $\mathbf{4 0 0}$ \\
\hline
\end{tabular}


It can be inferred from the above Table 9 that approximately $94 \%$ male and female (combined) in our sample had dependents from nil to 8 and in fact $70 \%$ of them had dependents 2 to 8 in our sample. One female from rural in, our sample, had more than 8 dependents on her whereas 2 females from urban had the same number of dependents.

Table 10 below represents the family monthly income-wise classification of the respondents:

Table 10: Passengers' Monthly Income

\begin{tabular}{|c|c|c|c|c|c|}
\hline Income & $\begin{array}{c}\text { Rural } \\
\text { (Male) }\end{array}$ & $\begin{array}{c}\text { Rural } \\
\text { (Female) }\end{array}$ & $\begin{array}{c}\text { Urban } \\
\text { (Male) }\end{array}$ & $\begin{array}{c}\text { Urban } \\
\text { (Female) }\end{array}$ & Total \\
\hline Upto Rs. 5,000 & 37 & 36 & 12 & 29 & $\mathbf{1 1 4}$ \\
\hline $\begin{array}{c}\text { Rs. 5,001 to } \\
\text { Rs. 10,000 }\end{array}$ & 28 & 07 & 31 & 42 & $\mathbf{1 4 3}$ \\
\hline $\begin{array}{c}\text { Rs. 10,001 to } \\
\text { Rs. 20,000 }\end{array}$ & 26 & 04 & 71 & 07 & $\mathbf{5 5}$ \\
\hline $\begin{array}{c}\text { More than } \\
\text { Rs. 20,000 }\end{array}$ & 09 & 03 & 36 & $\mathbf{1 0 0}$ & $\mathbf{4 0 0}$ \\
\hline \multicolumn{2}{|c|}{ Total } & $\mathbf{1 0 0}$ & $\mathbf{5 0}$ & $\mathbf{1 5 0}$ & \\
\hline
\end{tabular}

Source: Primary Data

It is evident from the table and data above that out of total sample only $18 \%$ rural passengers (combined) earned less than Rs. 5000 a month whereas $28 \%$ urban passengers (combined) earned between Rs. 10000 to 20000 a month. Overall about $50 \%$ of the combined passengers earned Rs. 10001 and more.

\section{9) RESULTS AND DISCUSSION}

After the conduction of the final survey, all the data collected were tabularized and statistical analysis was conducted. Table 11 below summarizes the 5point scale summary of the 13 attributes leading to results of levels of satisfaction of the passengers. The attribute numbers in the Table 11 represent the questions in the questionnaire (Appendix 1).

Table 11: 5-Point Scale Survey Summary and Analysis of the Data

\begin{tabular}{|c|c|c|c|c|c|c|c|c|}
\hline \multirow{2}{*}{$\begin{array}{c}\text { Attribute of } \\
\text { Service }\end{array}$} & \multicolumn{5}{|c|}{ Type of Response from Respondents } & \multirow[b]{2}{*}{$\begin{array}{c}\text { Total } \\
{[\mathbf{n}]}\end{array}$} & \multirow{2}{*}{$\begin{array}{l}\text { Calculated } \\
\text { Mean }\left[\boldsymbol{\mu}_{\mathrm{c}}\right]\end{array}$} & \multirow{2}{*}{$\begin{array}{l}\text { Expected } \\
\operatorname{Mean}\left[\boldsymbol{\mu}_{\mathrm{e}}\right]\end{array}$} \\
\hline & $\begin{array}{c}\text { V.Poor } \\
{[1]}\end{array}$ & $\begin{array}{c}\text { Poor } \\
{[2]}\end{array}$ & $\begin{array}{c}\text { Fair } \\
{[3]}\end{array}$ & $\begin{array}{c}\text { Good } \\
{[4]}\end{array}$ & $\begin{array}{c}\text { V.Good } \\
{[5]}\end{array}$ & & & \\
\hline Attribute 1 & 116 & 92 & 95 & 97 & 0 & 400 & 2.43 & 3.00 \\
\hline Attribute 2 & 92 & 85 & 81 & 75 & 67 & 400 & 2.85 & 3.00 \\
\hline Attribute 3 & 107 & 103 & 106 & 80 & 4 & 400 & 2.43 & 3.00 \\
\hline Attribute 4 & 78 & 74 & 98 & 94 & 56 & 400 & 2.94 & 3.00 \\
\hline Attribute 5 & 106 & 102 & 102 & 90 & 0 & 400 & 2.44 & 3.00 \\
\hline Attribute 6 & 113 & 100 & 95 & 86 & 6 & 400 & 2.43 & 3.00 \\
\hline Attribute 7 & 103 & 104 & 100 & 86 & 7 & 400 & 2.48 & 3.00 \\
\hline Attribute 8 & 79 & 105 & 100 & 80 & 36 & 400 & 2.72 & 3.00 \\
\hline Attribute 9 & 73 & 78 & 81 & 81 & 87 & 400 & 3.08 & 3.00 \\
\hline Attribute 10 & 134 & 144 & 63 & 47 & 12 & 400 & 2.15 & 3.00 \\
\hline Attribute 11 & 201 & 199 & 0 & 0 & 0 & 400 & 1.50 & 3.00 \\
\hline Attribute 12 & 35 & 93 & 101 & 92 & 79 & 400 & 3.22 & 3.00 \\
\hline Attribute 13 & 103 & 88 & 101 & 69 & 39 & 400 & 2.63 & 3.00 \\
\hline Total & 1340 & 1367 & 1123 & 977 & 393 & & 2.65 & 3.00 \\
\hline
\end{tabular}


It is evident from the Table 11 above that the expected overall mean is 3.00 and the calculated actual mean is 2.56 meaning that calculated mean is less than expected and hence can be inferred that overall the passengers are not satisfied towards the quality of the services being served by UPSRTC. Further, it is observed from the results above that attribute 11 (i.e. seat reservation facilities) shows highest dissatisfaction among customers whereas attribute 9 (i.e. travel using UPSRTC is economical) shows more than expected satisfied passengers. Rest of the attributes show, overall, passengers were negative towards the services offered by the corporation.

\section{0) CONCLUSION}

Consumer satisfaction is important because of its role in creating competitive advantage and significant attention in operations and marketing improvements. Highly satisfied customer show brand loyalty and remain customer to business for a longer span of time. These customers provide word-of-mouth advertising, which favors in increased revenues to a business. The aim of this research was to show the factors affecting passengers' satisfaction and with the outcomes of the results can be used by the corporation in managing the transportation services in better way by identifying the scopes (attributes) for improving the service qualities. In this way a segment can also be transferred from a low satisfaction level to a high level.

\section{1) FUTURE SCOPES AND LIMITATIONS OF THE STUDY}

In this paper passengers' satisfaction are measured by taking service quality attributes. Though this paper tried to analyze these attributes and performances but still there is a lot of scope exists for future research in this area. Also, this study is limited to Agra district only and it can be extended to other districts of the state to study the satisfaction levels of the passengers on a broader spectrum. More attributes can be added for deep understanding of the major quality factors of services that affect the overall satisfaction of the passengers. Further, research can also be done to study satisfaction levels among both genders and difference among the perception and expectations of passengers.

\section{ACKNOWLEDGEMENT}

One of the authors, Dr. Madhu Anand, gratefully acknowledges the financial support provided by the University Grants Commission, New Delhi, Government of India.

\section{REFERENCES}

1. Andreassen, T.W. (1995), "(Dis)satisfaction with public services: the case of public transportation", Journal of Services Marketing, Vol. 9, pp. 30-41.

2. Dawkins, P. and F. Reichheld (1990), "Customer Retention as a Competitive Weapon," Directors and Boards, Vol. 14 (Summer), pp. 42-47.

3. Disney, J. (1999). "Customer satisfaction and loyalty: The critical elements of service quality", Total Quality Management, Vol. 10 No. 4, pp. S491-S497.

4. Eboli, L. and Mazzulla, G. (2007), "Service quality aspects affecting customer satisfaction for bus transit", Journal of Public Transportation, Vol. 10 No. 3, pp. 21-34.

5. Jen, W., Tu, R., \& Lu, T. (2011). "Managing passenger behavioral intention: An integrated framework for service quality, satisfaction, perceived value, and switching barriers", Transportation, Vol. 38 No. 2, pp. 321-342.

6. Parasuraman, A., Zeithaml, V. A. and Berry, L.L. (1985), "A conceptual model of service quality and its implication for future research", Journal of Marketing, Vol. 49, pp. 41-50.

7. Parasuraman, A. and Berry, Leonard L. (1990), "Delivering Quality Service: Balancing Customer Perceptions and Expectations", New York: The Free Press.

8. Reichheld, Frederick and W. Earl Sasser, Jr. (1990), "Zero Defections: Quality Comes to Services", Harvard Business Review, Vol. 68 (September/October), pp. 105-11.

9. Yuan-Chih Huang, Chih-Hung $\mathrm{Wu}, \&$ Jovan Chia-Jung Hsu. (2006), "Using importanceperformance analysis in evaluating Taiwan medium and long distance national highway passenger transportation service quality", Journal of American Academy of Business, Cambridge, Vol. 8 No. 2, pp. 98-104.

10. UPSRTCS website (www.upsrtc.com): Accessed on November $2^{\text {nd }}, 2012$ 


\section{Appendix 1}

\section{Passenger Satisfaction Survey}

Dear Passenger,

This survey is designated to evaluate customers' satisfaction towards UPSRTC services. Please read the below survey questions carefully and respond with your true/unbiased opinion.

1. Are you commuting frequently by Buses:

\begin{tabular}{|l|l|}
\hline Yes & No \\
\hline
\end{tabular}

2. Are you commuting regularly using UPSRTC Buses:

\begin{tabular}{|l|l|}
\hline Yes & No \\
\hline
\end{tabular}

3. Are you also commuting by Private or Other State Transport Corporation's Buses:

\begin{tabular}{|l|l|}
\hline Yes & No \\
\hline
\end{tabular}

4. How much satisfied are you with the number of buses and general availability of UPSRTC buses on the route to your destination [Attribute 1]:

\begin{tabular}{|l|l|l|l|l|}
\hline Very Poor [1] & Poor [2] & Fair [3] & Good [4] & Very good [5] \\
\hline
\end{tabular}

5. How much satisfied are you with the timings (arrival, departure and travel) of buses from UPSRTC on the route to your destination [Attribute 2]:

\begin{tabular}{|l|l|l|l|l|}
\hline Very Poor [1] & Poor [2] & Fair [3] & Good [4] & Very good [5] \\
\hline
\end{tabular}

6. How much satisfied are you with the overall conditions (e.g. window glasses, seats, noise, tyre, luggage carrier, shock absorber etc) of the UPSRTC buses you travel from [Attribute 3]:

\begin{tabular}{|l|l|l|l|l|}
\hline Very Poor [1] & Poor [2] & Fair [3] & Good [4] & Very good [5] \\
\hline
\end{tabular}

7. How much satisfied are you with the behaviour of conductor and driver in the UPSRTC buses [Attribute 4]: 


\begin{tabular}{|l|l|l|l|l|} 
Very Poor [1] & Poor [2] & Fair [3] & Good [4] & Very good [5] \\
\hline
\end{tabular}

8. How much satisfied are you with the overall conditions (e.g. dust free, garbage free, floors, ambiance etc) of UPSRTC bus stands [Attribute 5]:

\begin{tabular}{|l|l|l|l|l|}
\hline Very Poor [1] & Poor [2] & Fair [3] & Good [4] & Very good [5] \\
\hline
\end{tabular}

9. How much satisfied are you with the cleanliness of UPSRTC bus stand amenities (e.g. toilets, waiting area, drinking water facilities, cloak room etc) [Attribute 6]:

\begin{tabular}{|l|l|l|l|l|}
\hline Very Poor [1] & Poor [2] & Fair [3] & Good [4] & Very good [5] \\
\hline
\end{tabular}

10. How much satisfied are you with the safety inside UPSRTC buses and bus stands [Attribute 7]:

\begin{tabular}{|l|l|l|l|l|}
\hline Very Poor [1] & Poor [2] & Fair [3] & Good [4] & Very good [5] \\
\hline
\end{tabular}

11. How much satisfied are you with the comfort inside UPSRTC buses while travelling [Attribute 8]:

\begin{tabular}{|l|l|l|l|l|}
\hline Very Poor [1] & Poor [2] & Fair [3] & Good [4] & Very good [5] \\
\hline
\end{tabular}

12. In your opinion, whether travel by UPSRTC buses is economical [Attribute 9]:

\begin{tabular}{|l|l|l|l|l|}
\hline Very Poor [1] & Poor [2] & Fair [3] & Good [4] & Very good [5] \\
\hline
\end{tabular}

13. Did you ever make a telephonic enquiry from UPSRTC customer care / bus stand

\begin{tabular}{|l|l|}
\hline No & Yes \\
\hline
\end{tabular}

If yes, then move to question no. 11, otherwise to question no. 12.

14. How much satisfied are you with the UPSRTC response to your telephone enquiry [Attribute 10]: 


\begin{tabular}{|l|l|l|l|l|}
\hline Very Poor [1] & Poor [2] & Fair [3] & Good [4] & Very good [5] \\
\hline
\end{tabular}

15. How much satisfied are you with the UPSRTC seat reservation facilities [Attribute 11]:

\begin{tabular}{|l|l|l|l|l|}
\hline Very Poor [1] & Poor [2] & Fair [3] & Good [4] & Very good [5] \\
\hline
\end{tabular}

16. How much satisfied are you with the availability and prices of food, snacks and eateries at UPSRTC bus stands [Attribute 12]:

\begin{tabular}{|l|l|l|l|l|}
\hline Very Poor [1] & Poor [2] & Fair [3] & Good [4] & Very good [5] \\
\hline
\end{tabular}

17. How much you rate UPSRTC buses as compare to its competitors (private or other state corporation buses) [Attribute 13]:

\begin{tabular}{|l|l|l|l|l|}
\hline Very Poor [1] & Poor [2] & Fair [3] & Good [4] & Very good [5] \\
\hline
\end{tabular}

18. Given the frequent and better alternatives to UPSRTC buses would you still be preferring UPSRTC buses as the primary mode of transportation:

\begin{tabular}{|l|l|}
\hline Yes & No \\
\hline
\end{tabular}

Now, we would like to know about your demographic and personal details. We assure you that below information is being collected purely for the analysis purposes only and we will not share your personal information with any third party.

19. Your Gender:

\begin{tabular}{|c|c|}
\hline Male & Female \\
\hline
\end{tabular}

20. Your Age (in years):

\begin{tabular}{|c|c|c|c|c|c|}
\hline Below 18 & $18-25$ & $26-35$ & $36-45$ & $46-55$ & $56 \&$ above \\
\hline
\end{tabular}

21. Your Locality: 


\begin{tabular}{|l|l|}
\hline Rural & Urban \\
\hline
\end{tabular}

22. Your Education:

\begin{tabular}{|c|c|c|c|c|}
\hline Illiterate & High School & Intermediate & Graduation & PG \& Above \\
\hline
\end{tabular}

23. Your Religion:

\begin{tabular}{|l|l|l|}
\hline Hindu & Muslim & Other \\
\hline
\end{tabular}

24. Your Caste:

\begin{tabular}{|l|l|l|}
\hline General & SC / ST & OBC \\
\hline
\end{tabular}

25. Your Occupation:

\begin{tabular}{|c|c|c|c|c|}
\hline Govt Job & Pvt Job & Business & Agriculture & Housewife / Student \\
\hline
\end{tabular}

26. Your Monthly Income (in Rupees):

\begin{tabular}{|l|l|l|l|}
\hline Upto 5,000 & $5,001-10,000$ & $10,001-20,000$ & More than 20,000 \\
\hline
\end{tabular}

27. Your Family System (Whether Living):

\begin{tabular}{|l|l|}
\hline Single / Nucleus Family & Joint / Combined Family \\
\hline
\end{tabular}

28. Number of Dependents on You:

\begin{tabular}{|l|l|l|l|l|}
\hline 0 to 1 & 2 to 3 & 4 to 5 & 6 to 8 & More than 8 \\
\hline
\end{tabular}

Thank you for your time and cooperation. 